\title{
Formulation and quality evaluation of instant mango drink powder
}

\author{
${ }^{1,2}$ Akther, S., ${ }^{2}$ Alim, M.A., ${ }^{1 *}$ Badsha, M.R., ${ }^{1}$ Matin, A., ${ }^{3}$ Ahmad, M. and ${ }^{1}$ Hoque, S.M.Z. \\ ${ }^{1}$ Department of Food Processing and Engineering, Chattogram Veterinary and Animal Sciences University, \\ Khulshi, Chattogram-4225, Bangladesh \\ ${ }^{2}$ Department of Food Technology and Rural Industries, Bangladesh Agricultural University, Mymensingh- \\ 2202, Bangladesh \\ ${ }^{3}$ Department of Applied Chemistry and Chemical Technology, Chattogram Veterinary and Animal Sciences \\ University, Khulshi, Chattogram-4225, Bangladesh
}

\begin{abstract}
Article history:
Received: 18 February 2020

Received in revised form: 14 March 2020

Accepted: 22 March 2020

Available Online: 8 March 2020
\end{abstract}

Keywords:

Instant mango drink powder, Formulation,

Proximate composition,

Bioactive compounds

DOI:

https://doi.org/10.26656/fr.2017.4(4).077

\begin{abstract}
The study was conducted to develop a healthy instant mango drink powder and to compare its nutritional facts with commercially available mango drink powder. For this purpose, ripe Amropali mangoes were collected from a local source. After drying the mango pulp in a cabinet dryer, three formulations were prepared to compare with a locally available commercial brand mango drink powder. In this study, moisture, ash, protein, fat, carbohydrate, and energy contents were ranged from 0.2 to $4.6 \%, 0.4$ to $2.6 \%, 0.7$ to $2.2 \%, 0.6$ to $0.9 \%, 89.5$ to $97.8 \%$ and 375.4 to $400.5 \mathrm{kcal} / 100 \mathrm{~g}$, respectively. The crude fiber was not found in any of the instant mango drink powder. Among the bioactive compounds, the flavonoid content in the commercial brand was higher than other formulated mango drink powder. In contrast, total anthocyanin content and total phenolic content values of all formulated instant mango drinks were higher than the commercial brand. Potassium, Magnesium, Chloride, Phosphorus, and Vitamin $\mathrm{C}$ were higher in formulated powder than the commercial preparation, but sodium, calcium, and iron contents were higher in the commercial mango drink powder. Antioxidant capacity was also found to be significantly higher in our formulated powder than that of commercial preparation. From the sensory and microbiological point of view, our formulated instant mango drink powder exhibited significant acceptability and stability. So, the formulated instant mango drink powder appears to be nutritionally and tastefully as acceptable as commercially available instant mango drink powders and able to meet day-to-day nutritional requirements as a supplement.
\end{abstract}

\section{Introduction}

Mango (Mangifera indica L.) is a well-known fruit cultivated in most frost-free tropical and warmer subtropical climates. Mangoes are often called the king of fruit due to their unique taste and flavor. The local name of this delicious fruit in Bangladesh is "aam", and it is cultivated in almost all districts in the country. Apart from the taste, the nutritional value of mango is unparalleled. Some popular verities of mangoes grown here include BARI AAM-3 (Amropali), Langra, Gopalbogh, Himsagar, Laksmanbhog, Mohanbhog, Misribhog, Khirsapat, Ashhwina, Khisanbogh, Kuapahadi, Fazlee, Lata, Bombai, Foria, Kohitoor, etc. BARI AAM-3 is a recent addition of sweet and nonfibrous flesh containing mango cultivated in most parts of Bangladesh. Bangladesh ranks $8^{\text {th }}$ in terms of mango production. Other major mango producing countries are India, Pakistan, Mexico, Brazil, Philippines (Alam et al., 2006).

People around the world love mangoes due to their flavor and color, along with their nutritional value. Sweet aroma, attractive peel color, delicious taste is supplemented by high contents of vitamin $C, \beta$-carotene, and trace elements. Mango contains several types of polyphenols, including mangiferin, which is a powerful antioxidant. It is an excellent source of several vitamins like folate, some B vitamins, vitamins A, C, E, and K. Folate is vital for normal cell growth and hemoglobin synthesis. Vitamin B helps in many cellular functions, while others improve immunity. Among minerals, 
mango is rich in potassium and magnesium, which are essential in the normal cardiac function of humans. Its lutein, zeaxanthin, and vitamin A help in vision protect eyes from harmful sunrays and prevent night blindness. Vitamin A also keeps skin and hair healthy. Mango polyphenols, which are considered antioxidants, remove harmful free radicals from our body and thus reduce the risk of various cancers like lung, breast, stomach, and colon cancers. The chemical composition of mango pulp varies with soil quality, variety, and stage of maturity. Naturally, fructose and sucrose content of ripe mango is more than that of green mango. Major phenolic compounds found in mango so far include leucocyanidin, catechin, epicatechin, chlorogenic acid, quercitrin, quercetin, (Ma et al., 2011). Mango contains some pigments like chlorophylls and carotenoids, particularly after ripening, which confer UV skin protection (Ma et al., 2011; Kabir et al., 2017).

Bangladesh is a fertile land for mango cultivation. It is also one of the important commercial fruit crops, with yearly production exceeding 1.1 million metric tons. After meeting local demands, mango is exported to several countries. However, a large portion of a ripe mango is wasted at different production points due to low-tech processing, poor transportation, and inadequate storage facilities. Proper utilization of mango in producer country, including export to suitable markets, is invariably limited by the perishable nature of the fruit and the short harvest season of the crop. In addition to direct consumption, mangoes are processed in various forms for long-term storage. Mango juice is one such preparation that is extremely popular, particularly among children. Mango pulp is also converted to mango nectar, puree, beverages, and powder. Mango powder is a relatively stable preparation that can be used in drinks, desserts, confectionaries, baby foods, and many other products.

Dehydrating mango juice into powdered particles not only reduces volume for more cost-effective transportation but prolongs the shelf life effectively as well (Mahendran, 2011). Powdered mango juice is mainly used as instant food. These products can stay unaltered in more extremes of temperature and for a more extended period than liquid preparations (Pap, 1995). Fruit powders are also used in many food items with convenience. If the moisture content of fruit powders can be reduced to less than $4 \%$, they can be used to make candy, toffee, fudge, etc. People, particularly children who do not like raw mango, may find these food products more appetizing. The moisture content of mango pulp is very high $(85 \%)$, rendering it challenging to store long-term, particularly in adverse climatic conditions. This results in wastage of almost
$30 \%$ of fruits every year (Thind et al., 2002). To minimize this post-harvest loss and to improve shelf-life, various attempts have been made to process the surplus mango into something more stable. Dried flakes and powders, and preservative-added pulp are some of the successful outcomes of such attempts (Saxena and Arora, 1997). Mango powder is required in the production of various mango-flavored foods like ice cream, fruit bar, cake, cereal flakes, etc. As a result, there is a huge demand for a non-caking and soluble mango powder in the food industry (Akhter et al., 2010). Several techniques have been developed to produce powder from mango pulp, such as cabinet drying, spray drying, freezedrying, foam mat drying, drum drying, and vacuum drying. A practical and handy application of mango pulp powder is the preparation of instant mango drink powder.

Powdered drink mix is a processed-food product, a powder designed to mix usually with water to produce a beverage resembling fruit juice or soda in flavor. The instant mango drink powder mainly consists of natural mango powders, sweetening agent, color source, flavor source, thickening agent, anticaking agent, acid source, and additives, which make it's desirable, appealing, appetizing, delicious, informative, and nutritious for our health. There is a huge demand for mango drinks in the summer season because it provides instant rehydration and a sense of freshness. Instant mango drink powder can easily meet this demand and help people get a highenergy, refreshing, and flavored drink with additional vitamins and minerals (Chen et al., 2000). The powder form of mango juice can be used for breakfast as well because it takes only seconds to prepare a drink by mixing water, which saves time in the morning considerably. Mango drink powder may attract consumer attention if they are made aware of this product with a focus on taste, mixed and attractive color, mixed flavor, and handiness. So, the objectives of this study were to formulate instant mango drink powder and to evaluate the proximate composition, mineral analysis, bioactive compounds (phenolic content, flavonoid content, anthocyanin content, and antioxidant capacity), sensory evaluation and microbiological quality of the instant mango drink powder.

\section{Materials and methods}

\subsection{Materials}

Ripe Amropali mangoes were collected from Bangladesh Agriculture Research Institute, Pahartali, Chattogram, Bangladesh. Sugar and salt were purchased from the local market. Other ingredients (Citric Acid, Trisodium Citrate, Tricalcium Phosphate, Ascorbic Acid, Aspartame, Titanium Dioxide, CMC, Silicon dioxide, 
Color (E110, E102), and Flavor) and Chemicals used in this study were of laboratory grade procured from Merck KGaA, Darmstadt, Germany.

\subsection{Formulation of instant mango drink powder}

\subsubsection{Preparation of mango pulp powder}

The freshly collected mangoes were made sure to free from insect's bites or worms and washed with water to eliminate visible dirt. Water was removed quickly with blotting papers. The ripe mangoes were trimmed to remove the stem and blossom end. The mangoes were then peeled manually; the pulp was separated from the seeds and blended in a household blender to make it uniform. Before the drying process, the pulp was sieved using a sieve in order to remove large particles and insoluble fibers. The pulp was then placed in a cabinet dryer. The cabinet-dried content was collected after three days and was ground into powder. The powder was then sieved to remove large fragments. The yield was considered as mango powder. The exact amount was weighed and taken as required for different analyses.

\subsubsection{Processing of instant mango drink powder}

Table 1. Formulation of instant mango drink powder

\begin{tabular}{|c|c|c|c|}
\hline Ingredients & $\begin{array}{c}\text { Formulation } \\
1\end{array}$ & $\begin{array}{c}\text { Formulation } \\
2\end{array}$ & $\begin{array}{c}\text { Formulation } \\
3\end{array}$ \\
\hline Sugar & $975 \mathrm{~g}$ & $975 \mathrm{~g}$ & $975 \mathrm{~g}$ \\
\hline Citric Acid & $55 \mathrm{~g}$ & $55 \mathrm{~g}$ & $55 \mathrm{~g}$ \\
\hline Trisodium citrate & $12 \mathrm{~g}$ & $12 \mathrm{~g}$ & $12 \mathrm{~g}$ \\
\hline Tricalcium Phosphate & $06 \mathrm{~g}$ & $06 \mathrm{~g}$ & $06 \mathrm{~g}$ \\
\hline Ascorbic Acid & $12 \mathrm{~g}$ & $12 \mathrm{~g}$ & $12 \mathrm{~g}$ \\
\hline Aspartame & $12 \mathrm{~g}$ & $12 \mathrm{~g}$ & $12 \mathrm{~g}$ \\
\hline Salt & $20 \mathrm{~g}$ & $20 \mathrm{~g}$ & $20 \mathrm{~g}$ \\
\hline Titanium Dioxide & $02 \mathrm{~g}$ & $02 \mathrm{~g}$ & $02 \mathrm{~g}$ \\
\hline $\mathrm{CMC}$ & $06 \mathrm{~g}$ & $06 \mathrm{~g}$ & $06 \mathrm{~g}$ \\
\hline Silicon di oxide & $01 \mathrm{~g}$ & $01 \mathrm{~g}$ & $01 \mathrm{~g}$ \\
\hline Mango Powder & $278 \mathrm{~g}$ & $196 \mathrm{~g}$ & $124 \mathrm{~g}$ \\
\hline Color (E110, E102) & $1.5 \mathrm{~g}$ & $1.5 \mathrm{~g}$ & $1.5 \mathrm{~g}$ \\
\hline Flavor & $10 \mathrm{~g}$ & $10 \mathrm{~g}$ & $10 \mathrm{~g}$ \\
\hline
\end{tabular}

Various trials were carried out to formulate the instant mango drink powder. Finally, the formulation of instant mango drink powders, according to Table 1. From Table 1, Sample A, B, C, and D represented Formulation one (20\% mango powder), Formulation two ( $15 \%$ mango powder), Formulation three (10\% mango powder), and commercial brand of instant mango drink powder respectively. Sugar, citric acid, trisodium citrate, tricalcium phosphate, ascorbic acid, aspartame, salt, titanium dioxide, CMC, silicon dioxide, color (E110, E102), and flavor were added to the selected sample of mango powder after weighing according to the quantities given in Table 1. They were mixed thoroughly and ground for uniform distribution of ingredients. The processed instant mango drink powder be packaged and stored for sensory evaluation, nutritive value, and other analyses.

\subsection{Quality evaluation of instant mango drink powder}

\subsubsection{Proximate analysis of instant mango drink powder}

The proximate compositions of the instant mango drink powder were determined using methods described by (AOAC) Association of Official Analytical Chemists (AOAC, 2000) with certain modifications. The total carbohydrate was calculated as the difference between 100 and a sum total of the other proximate components. Therefore, the formula became:

$\% \mathrm{CHO}=100 \%-\%($ Protein + Fat + Fiber + Ash + Moisture content).

The energy value of the samples was determined by multiplying the protein content by four, carbohydrate content by four and fat content by nine according to standard James formula (James, 1995).

Energy Value $=($ Crude protein $\times 4)+($ Total carbohydrate $\times 4)+($ Crude fat $\times 9)$

\subsubsection{Mineral analysis of instant mango drink powder}

The preparation of samples for mineral analysis was done using the method described by Mustafa and Medeiros (1985). Sample of $1 \mathrm{~g}$ was added with $10 \mathrm{~mL}$ nitric acid and $5 \mathrm{~mL} \mathrm{HClO}_{4}$ acid in a digestion flask. The mixture was digested for $1 \mathrm{hr}$. The digested mixture was filtered. The filtrate was made up to $100 \mathrm{~mL}$ with distilled water. Mineral contents were determined by using a biochemical analyzer (Humalyzer 3000). Commercially available biochemical kit (Randox $\left.{ }^{\circledR}\right)$ was used for biochemical assay. The quantity of the vitamin $\mathrm{C}$ contained in each sample was determined by the titrimetric method (using 2, 6-dichlorophenol indophenol dye) described by Najwa and Azrina (2017).

\subsubsection{Bioactive compounds of instant mango drink powder}

\subsubsection{Preparation of extracts}

The preparation of extracts for measuring bioactive compounds was done according to a modified method described by Unal et al. (2014). Cabinet-dried samples of mango pulp were transferred into respective beakers containing absolute ethanol and left to shake on a shaker for $72 \mathrm{hrs}$ at room temperature. The solvent was then separated from residue by straining. The filtrate was collected and stored at room temperature. At the same time, the residue was re-extracted twice, each time with fresh solvent. Finally, all the filtrates were combined and 
evaporated under reduced pressure at $60^{\circ} \mathrm{C}$ using a rotary evaporator to obtain the crude extracts. The crude extracts were weighed and stored at $4{ }^{\circ} \mathrm{C}$ until further analysis.

\subsubsection{Total anthocyanin content (TAC)}

TAC of the instant mango drink powder extracts was determined calorimetrically using the method described by Unal et al. (2014) with slight modifications. Stock solutions of $15 \mathrm{mg} / \mathrm{mL}$ of extracts were prepared. $3 \mathrm{~mL}$ of solution was pipetted into a cuvette. The intensity of the extracted color was measured at a wavelength of 520 $\mathrm{nm}$ using a UV-VIS spectrophotometer. Absolute ethanol was used as a blank. TAC was calculated and expressed as milligrams per $100 \mathrm{~g}(\mathrm{mg} / 100 \mathrm{~g})$ using the following equation:

\section{$\mathrm{TAC}=$ Absorbance of sample $\times \mathrm{DF} \times 100 / \mathrm{m} \times \mathrm{E}$}

Where DF stands for dilution factor, $\mathrm{m}$ indicates the weight of the sample used to make a stock solution; and E refers to the extinction coefficient (55.9).

\subsubsection{Total flavonoid content (TFC)}

TFC of the instant mango drink powder extracts was determined using the aluminum chloride colorimetric method described by Chang et al. (2002). A stock solution of $1 \mathrm{mg} / \mathrm{mL}$ of extracts was prepared. Quercetin was dissolved in $80 \%$ ethanol to make standard solutions $(1.0,3.0,5.0$, and $7.0 \mathrm{mg} / \mathrm{mL})$ to plot a standard curve. Aliquots of $0.5 \mathrm{~mL}$ of diluted extract or standard solution were mixed with $1.5 \mathrm{~mL}$ of $95 \%$ ethanol, $0.1 \mathrm{~mL}$ of $10 \%$ aluminum chloride, $0.1 \mathrm{~mL}$ of $1 \mathrm{~mol} / \mathrm{L}$ potassium acetate, and $2.8 \mathrm{~mL}$ of distilled water in the cuvette. The mixture was left at room temperature for $30 \mathrm{~min}$. The absorbance was read at wavelength $415 \mathrm{~nm}$ in a UVvisible spectrophotometer. For the blank, $10 \%$ aluminum chloride was substituted with distilled water of the same amount. TFC was calculated and expressed as milligrams quercetin equivalents $(\mathrm{QE})$ per gram of extract $(\mathrm{mg} \mathrm{QE} /$ g).

\subsubsection{Total phenolic content (TPC)}

TPC of the instant mango drink powder extracts was determined according to the method described by Unal et al. (2014) with slight modifications. Standard solutions of $1 \mathrm{mg} / \mathrm{mL}$ of extracts and standard solutions of Gallic acid $(1.0,2.0,4.0,6.0,8.0 \mathrm{mg} / \mathrm{mL})$ were prepared. 0.3 $\mathrm{mL}$ of extracts and Gallic acid standard solutions were pipetted into a cuvette individually. Diluted FC reagent $(1.5 \mathrm{~mL})$ was then added and mixed. The mixtures were left for 3 min before adding $1.5 \mathrm{~mL}$ of sodium carbonate $(75 \mathrm{~g} / \mathrm{L})$ solution and the mixtures were again left for 60 min. The absorbance was measured at a wavelength of
$765 \mathrm{~nm}$ using a UV spectrophotometer with ethanol using as the blank. TPC was calculated and expressed as milligrams of Gallic acid equivalents (GAE) per gram of extracts (mg GAE/g).

\subsubsection{Antioxidants properties of instant mango drink powder}

Antioxidant capacity of the extracts was determined using DPPH assay as described by Azlim Almey et al. (2010) with slight modifications. Different dilutions $(0.50,1.00,1.50,2.00$, and $2.50 \mathrm{mg} / \mathrm{mL})$ of the extract were prepared using methanol. The methanolic DPPH solution was prepared by dissolving $6 \mathrm{mg}$ of DPPH in $100 \mathrm{~mL}$ methanol. The methanolic DPPH solution (2 $\mathrm{mL}$ ) was added to $1 \mathrm{~mL}$ of each extract solution of different concentrations, and the mixture was left for 30 min. The absorbance was read at a wavelength of 517 $\mathrm{nm}$ using a UV spectrophotometer. Control was prepared by mixing $1 \mathrm{~mL}$ of methanol with $2 \mathrm{~mL}$ of DPPH solution. Methanol was used as a blank, while Trolox was used as a standard. Antioxidant capacity based on the DPPH free radical scavenging ability of the extracts was calculated and expressed as milligrams of Trolox equivalents (TE) per gram of extracts (mg TE/g).

\subsection{Sensory evaluation of instant mango drink powder}

The evaluation of instant mango drinks was carried out using a scorecard developed for the purpose. The scorecard was prepared, considering the quality characteristics of the products. Descriptive terms were given to various quality attributes like appearance/color, flavor, taste, and general acceptance. Each attribute of the samples was scored by the panelists on a visual analog scale. The scale was arranged such that: Like extremely $=9$, Like very much $=8$, Like moderately $=7$, Like slightly $=6$, Neither like nor dislike $=5$, Dislike slight $=4$, Dislike moderately $=3$, Dislike very much $=$ 2 , Dislike Extremely $=1$. While scoring, the highest score (9) was assigned to the most preferred characteristic and least score (1) to the least desired characteristic. While this evaluation does not reflect actual consumer perception, it gives an idea of what attributes a good quality product should possess.

\subsection{Microbiological quality of the instant mango drink powder}

The total viable count was carried out by using plate count agar medium according to a standard procedure (Atallah, 2015). Colony count was done using a digital colony counter, and the total viable count was expressed as colony-forming units per $\mathrm{mL}(\mathrm{CFU} / \mathrm{mL})$. Total coliform and E. coli count was done according to Standard Methods (Pitkanen et al., 2007). Yeast and mold count was carried out according to Seiler, (1985). 
The result was expressed as yeast and mold growth was present or not.

\subsection{Statistical analysis}

Data (proximate composition, minerals content, bioactive compounds, and sensory evaluation) for statistical analysis were determined and recorded in Microsoft Excel 2013 spreadsheet. All samples were in three replicates. Data were then sorted, coded, and recorded in IBM SPSS Statistics 23. Descriptive statistics (mean, standard deviation) were conducted for proximate composition, mineral contents, bioactive compounds, and sensory evaluation of instant mango drink powder. These data were further analyzed using one-way ANOVA tests to assess significant levels of variation at a $95 \%$ confidence interval. Post hoc "Tukey" test was conducted to identify the variation within the sample groups. The statistical analysis was conducted at a $5 \%$ level of significance $(\mathrm{P}<0.05)$.

\section{Results and discussion}

\subsection{Formulation of instant mango drink powder and its composition}

Simple unit operations working in the formulation of instant mango drink powder, where firstly mango pulp powder was prepared, then mixing with other ingredients, grinding, and finally packing. Among three formulated instant drinks powder, 20\% mango pulp powders were used in formulation one, $15 \%$ mango powder in formulation two and $10 \%$ mango powder in formulation three, respectively. In order to feel the pure taste of farm-fresh fruit, natural mango powders were used. Additionally, other ingredients were used as the same amount in all formulated instant mango drink powder with each individual purpose. Such as aspartame provides a sweet taste like that of sugar while containing significantly less food energy than sugar-based sweeteners (Kroger et al., 2006). Food color (E110, E102) are used to make food more attractive, appealing, appetizing, and informative (Khodjaeva et al., 2013). Flavoring agent is used to enhancing flavor of the products, and Carboxymethyl cellulose (CMC) are used to increase the viscosity of a liquid without substantially changing its other properties and additionally may improve the suspension of other ingredients or emulsions which increases the stability of the product (McClements, 2015). Tricalcium Phosphate is an additive placed in powdered or granulated materials to prevent the formation of lumps (caking) and for easing packaging, transport, flowability, and consumption (Luck and von Rymon Lipinski, 2002). Citric acid, ascorbic acid is added to make its flavors "sharper" and also act as preservatives and antioxidants (Mirza et al., 2017). Trisodium citrate is used to change or control the acidity \& alkalinity of foods (Kermode, 1972). Silica is a common additive in food production, where it is used primarily as a flow agent in powdered foods to adsorb water in hygroscopic applications (Fitzpatrick, 2005). A glass of instant mango drink powder is a great way to start the day (Swartzberg and Margen, 2001). Formulated Instant mango drink powder contains many nutrients with vitamin $\mathrm{C}$ and minerals, depending on the brand and product.

\subsection{Proximate analysis of instant mango drink powder}

Proximate composition of three formulated instant mango drink powder and one commercial brand of instant mango drink powder has been shown in Table 2 . The results of moisture content ranged from 4.6 to $0.2 \%$ for different samples of instant mango drink powder. Sample A had the highest moisture content $(4.6 \pm 0.04 \%)$ whereas Sample D had the lowest value $(0.2 \pm 0.01 \%)$. The results of the Moisture content showed that the samples were significantly different $(p<0.05)$. The moisture content of food products is an important indicator of food quality and long-term usability because increased moisture facilitates the growth of microbes and ultimately reduces quality by damaging them early. The moisture content of our instant mango drink powder was slightly higher than the reports of Akhter et al. (2010) for instant mango powder; Farzana et al. (2017) for vegetable soup powder. The moisture contents of the instant mango drink powder were lower than reported by Mohammed et al. (2017) for instant sorrel (Zobo) drink and Obilana et al. (2018) for instant beverage powder.

Table 2. Proximate analysis of instant mango drink powder

\begin{tabular}{lcccc}
\hline \multirow{2}{*}{ Parameter } & \multicolumn{4}{c}{ Sample } \\
\cline { 2 - 5 } & $\mathrm{A}$ & $\mathrm{B}$ & $\mathrm{C}$ & $\mathrm{D}$ \\
\hline Moisture (\%) & $4.6 \pm 0.04^{\mathrm{a}}$ & $4.4 \pm 0.02^{\mathrm{b}}$ & $4.4 \pm 0.02^{\mathrm{b}}$ & $0.2 \pm 0.01^{\mathrm{c}}$ \\
Ash (\%) & $2.6 \pm 0.02^{\mathrm{a}}$ & $2.3 \pm 0.03^{\mathrm{b}}$ & $1.1 \pm 0.01^{\mathrm{c}}$ & $0.4 \pm 0.02^{\mathrm{d}}$ \\
Protein (\%) & $2.2 \pm 0.02^{\mathrm{a}}$ & $2.0 \pm 0.02^{\mathrm{b}}$ & $1.1 \pm 0.01^{\mathrm{c}}$ & $0.7 \pm 0.03^{\mathrm{d}}$ \\
Fat (\%) & $0.9 \pm 0.03^{\mathrm{a}}$ & $0.8 \pm 0.04^{\mathrm{b}}$ & $0.6 \pm 0.01^{\mathrm{d}}$ & $0.6 \pm 0.01^{\mathrm{c}}$ \\
Carbohydrate (\%) & $89.5 \pm 0.20^{\mathrm{d}}$ & $90.3 \pm 0.01^{\mathrm{c}}$ & $92.6 \pm 0.01^{\mathrm{b}}$ & $97.8 \pm 0.04^{\mathrm{a}}$ \\
Energy (Kcal/100 g) & $375.4 \pm 0.02^{\mathrm{d}}$ & $376.8 \pm 0.02^{\mathrm{c}}$ & $380.7 \pm 0.03^{\mathrm{b}}$ & $400.5 \pm 0.03^{\mathrm{a}}$ \\
\hline
\end{tabular}

Significant at $\mathrm{P}<0.05$; Values followed by different superscript letters within the same row denote a significant difference. 
Moisture content below $8 \%$ helps to prevent the growth of microorganisms in food, while a level greater than $18 \%$ enables some microbes to grow. El Wakeel (2007) claimed that moisture content less than $10 \%$ is ideal for dried food products like instant drinks powder.

Ash content was highest in sample A $(2.6 \pm 0.02 \%)$ and lowest in Sample D (0.4 $\pm 0.02 \%)$. The results of ash content showed that the samples were significantly different $(p<0.05)$. The higher ash content of our formulated instant drinks powder indicates that these are a better source of minerals. The ash contents of the instant mango drink powder were higher than reported by Akhter et al., (2010) for instant mango juice powder; Mohammed et al. (2017) for instant sorrel (Zobo) drink and lower than reported by Farzana et al. (2017) for vegetable soup powder and similar than reported by Obilana et al. (2018) for instant beverage powder.

Fruits and vegetables are known for low protein and crude fat. Sample A yielded the highest protein content $(2.2 \pm 0.02 \%)$. In contrast, the lower value $(0.7 \pm 0.03 \%)$ was found in Sample D. The results of protein content showed that the samples were significantly different $(p<0.05)$. The protein content of the instant mango drink powder was higher than reported by Akhter et al. (2010) for instant mango juice powder and lower than reported by Farzana et al. (2017) for vegetable soup powder, Mohammed et al. (2017) for instant sorrel (Zobo) drink and Obilana et al. (2018) for instant beverage powder.

All samples of formulated mango drink powder and commercial drinks powder showed almost similar fat content. The result of other studies for this particular attribute is variable. The results of fat content showed that the samples were significantly different $(p<0.05)$. Our study is consistent with that of Akhter et al. (2010) when it comes to fat content, but Mohammed et al. (2017) found higher fat content. Fat is a concentrated source of energy that is stored in the body and utilized when carbohydrate source is depleted. Another important function of fat is to act as a cushion and protect internal organs, including the heart, kidneys, lungs, and intestine (Mohammed et al., 2017).

Carbohydrate content was higher in Sample D $(97.8 \pm 0.04 \%)$ than that of Sample A, B and C. The carbohydrate content of our formulated mango drink powder is lower than that of the commercial brand of instant mango drink powder. The results of the carbohydrate content showed that the samples were significantly different $(\mathrm{p}<0.05)$. The carbohydrate content of our formulated instant drinks powder was, therefore, at an acceptable level, which would work as a good source of energy. The carbohydrate contents of the instant mango drink powder were higher than reported by Mohammed et al. (2017) for instant sorrel (Zobo) drink, Farzana et al. (2017) for vegetable soup powder and Obilana et al. (2018) for instant beverage powder.

Alternatively, when calculated for energy, Sample D scored the highest $(400.5 \pm 0.03 \mathrm{kcal} / 100 \mathrm{~g})$, and Sample A scored the lowest $(375.4 \pm 0.02 \mathrm{kcal} / 100 \mathrm{~g})$. The energy content of all formulated instant mango drink powder was found to be lower than that of the commercial brand of instant mango drink powder. This lower value may be attributed to the lower fat and carbohydrate contents of our preparations. The results of energy content showed that the samples were significantly different $(p<0.05)$. The energy value of the instant mango drink powder was similar than reported by Mohammed et al. (2017) for instant sorrel (Zobo) drink and lower than observed by Farzana et al. (2017) for vegetable soup powder and Obilana et al. (2018) for instant beverage powder.

The proximate analysis of our formulated instant mango drink powder indicates that most attributes ranked superior to the commercial instant drinks powder. The proximate analysis of the instant drinks powder indicates that it is good for human consumption. Proximate analysis is of utmost importance in commercial food-manufacturing processes because the companies need to make sure that their products meet the appropriate laws and legal requirements as well as safety and nutritional aspects of the end products. It remains the only means of maintaining and monitoring the quality and shelf life of food products (Johnson and Raymond, 1965).

\subsection{Vitamin $C$ and mineral contents of instant mango drink powder}

Table 3 shows the mineral contents of three formulated instant mango drink powder and one commercial brand of instant mango drink powder. The results of mineral contents and Vitamin $\mathrm{C}$ were found in all instant mango drink powder samples in the range as $\mathrm{Na}(230.2-109.3 \mathrm{mg} / \mathrm{dL}), \mathrm{K}(3.9-2.0 \mathrm{mg} / \mathrm{dL}), \mathrm{Ca}(8.2-3.6$ $\mathrm{mg} / \mathrm{dL}), \mathrm{Mg}(1.8-0.5 \mathrm{mg} / \mathrm{dL}), \mathrm{Cl}(57.8-9.5 \mathrm{mg} / \mathrm{dL}), \mathrm{P}$ $(5.5-2.2 \mathrm{mg} / \mathrm{dL}), \mathrm{Fe}(0.182-0.092 \mathrm{mg} / \mathrm{dL})$ and Vitamin C (584.6-208.4 mg/dL). Potassium, magnesium, chloride, phosphorus, and Vitamin $\mathrm{C}$ were higher in Sample A than the rest. However, sodium, calcium, and iron were highest in Sample D. Sample C had the lowest levels of sodium, calcium, potassium, phosphorus, and iron. Magnesium, chloride, and Vitamin $\mathrm{C}$ were lowest in Sample D. The results of mineral content showed that the samples were significantly different $(p<0.05)$. Vitamins and minerals play an important role in metabolic and synthetic activities in the body, thereby help in maintaining the sound health of the human body. Diet deficient in minerals is frequently associated with 
Table 3. Mineral contents of instant mango drink powder

\begin{tabular}{lcccc}
\hline \multirow{2}{*}{ Mineral Contents } & \multicolumn{4}{c}{ Sample } \\
\cline { 2 - 5 } & $189.5 \pm 0.04^{\mathrm{b}}$ & $149.4 \pm 0.04^{\mathrm{c}}$ & $109.3 \pm 0.03^{\mathrm{d}}$ & $230.2 \pm 0.03^{\mathrm{a}}$ \\
$\mathrm{nyyyy}(\mathrm{mg} / \mathrm{dl})$ & $3.9 \pm 0.03^{\mathrm{a}}$ & $2.7 \pm 0.03^{\mathrm{b}}$ & $2.0 \pm 0.01^{\mathrm{d}}$ & $2.3 \pm 0.01^{\mathrm{c}}$ \\
$\mathrm{K}(\mathrm{mg} / \mathrm{dl})$ & $5.7 \pm 0.04^{\mathrm{b}}$ & $4.4 \pm 0.07^{\mathrm{c}}$ & $3.6 \pm 0.04^{\mathrm{d}}$ & $8.2 \pm 0.04^{\mathrm{a}}$ \\
$\mathrm{Ca}(\mathrm{mg} / \mathrm{dl})$ & $1.8 \pm 0.03^{\mathrm{a}}$ & $1.2 \pm 0.2^{\mathrm{b}}$ & $0.6 \pm 0.2^{\mathrm{c}}$ & $0.5 \pm 0.02^{\mathrm{d}}$ \\
$\mathrm{Mg}(\mathrm{mg} / \mathrm{dl})$ & $57.8 \pm 0.02^{\mathrm{a}}$ & $55.0 \pm 0.02^{\mathrm{b}}$ & $54.3 \pm 0.03^{\mathrm{c}}$ & $9.5 \pm 0.02^{\mathrm{d}}$ \\
$\mathrm{Cl}(\mathrm{mg} / \mathrm{dl})$ & $5.5 \pm 0.02^{\mathrm{a}}$ & $4.3 \pm 0.02^{\mathrm{b}}$ & $2.2 \pm 0.03^{\mathrm{d}}$ & $2.4 \pm 0.02^{\mathrm{c}}$ \\
$\mathrm{P}(\mathrm{mg} / \mathrm{dl})$ & $0.133 \pm 0.004^{\mathrm{b}}$ & $0.116 \pm 0.001^{\mathrm{c}}$ & $0.092 \pm 0.005^{\mathrm{d}}$ & $0.182 \pm 0.004^{\mathrm{a}}$ \\
$\mathrm{Fe}(\mathrm{mg} / \mathrm{dl})$ & $584.6 \pm 0.5^{\mathrm{a}}$ & $574.6 \pm 0.03^{\mathrm{b}}$ & $510.5 \pm 0.14^{\mathrm{c}}$ & $208.4 \pm 0.05^{\mathrm{d}}$ \\
Vit-C (mg/dl) & &
\end{tabular}

Significant at $\mathrm{P}<0.05$; Values followed by different superscript letters within the same row denote a significant difference.

increased susceptibility to infection and inadequate growth and development. In this study, the levels of trace elements and vitamin $\mathrm{C}$ were considerably variable among formulated instant mango drink powder and commercial brand of mango drink powder. The vitamin C content of Sample D was lower than that of our formulated samples (A, B, and C). It indicates that instant mango drink powder may be a good source of vitamin C. Obilana et al. (2018) prepared instant beverage powder from extruded malted pearl millet (Babla) reported the calcium content as $32.56 \mathrm{mg} / 100 \mathrm{~g}$ ) and the iron content as $7.78 \mathrm{mg} / 100 \mathrm{~g}$. Farzana et al. (2017) prepared soup powder from vegetable reported the Vitamin C content as $6.4 \mathrm{mg} / 100 \mathrm{~g}$.

\subsection{Bioactive compounds of instant mango drink powder}

Bioactive compounds of three formulations of instant mango drink powder and one commercial brand of such products are shown in Table 4. The levels of total bioactive compounds were different among formulated instant mango drink powder preparations and commercial brand powder. On the other hand, total anthocyanin content and total phenolic content values of all formulated instant mango drinks were higher than the commercial brand. The results of bioactive compounds showed that the samples were significantly different $(\mathrm{p}<0.05)$. No previous studies were not found on bioactive compounds of instant mango drink powder.

The results of total anthocyanin content ranged from 0.2-0.9 mg/100 g for different Sample of instant mango drink powder. Sample A had the highest total anthocyanin content (TAC) $(0.9 \pm 0.00 \quad \mathrm{mg} / 100 \mathrm{~g})$, whereas Sample D had the lowest value $(0.2 \pm 0.00$ $\mathrm{mg} / 100 \mathrm{~g})$. The results of total flavonoid content ranged from 19.0-32.2 mg QE/100 $\mathrm{g}$ for a different brand of instant mango drink powder. Total flavonoid content (TFC) was highest $(32.2 \pm 0.02 \mathrm{mg} \mathrm{QE} / 100 \mathrm{~g})$ in Sample $\mathrm{D}$, and lowest $(19.0 \pm 0.01 \mathrm{mg} \mathrm{QE} / 100 \mathrm{~g})$ in Sample C. The flavonoid content in the commercial brand was higher than other formulated mango drink powder. The results of total phenolic content ranged from $5.0-32.8 \mathrm{mg}$ $\mathrm{GAE} / 100 \mathrm{~g}$ for a different brand of instant mango drink powder. Total phenolic content (TPC) was highest $(32.8 \pm 0.03 \mathrm{GAE} \mathrm{mg} / 100 \mathrm{~g})$ in Sample A and lowest $(5.0 \pm 0.10 \mathrm{GAE} \mathrm{mg} / 100 \mathrm{~g})$ in Sample D. Obilana et al. (2018) prepared instant beverage powder from extruded malted pearl millet (Babla) reported the total phenolic content as $1.30 \mu \mathrm{g} / \mathrm{g}$. Total phenolic content was significantly higher in the formulated preparation than that of the commercial brand, indicating potential higher antioxidant activity of the formulated preparation. Dietary intake of polyphenolic compounds has been estimated to be between 0.15 and $1.0 \mathrm{~g} /$ day.

The results of antioxidant capacity ranged from 19.7$28.0 \mathrm{mg}$ TE/100 $\mathrm{g}$ for a different brand of instant mango drink powder. Antioxidant Capacity content in Sample C was comparatively higher $(28.0 \pm 0.02 \mathrm{mg} \mathrm{TE} / 100 \mathrm{~g})$ than that of Sample D (19.7 $\pm 0.02 \mathrm{mg}$ TE/100 g). Formulation A showed the highest antioxidant capacity among all the samples based on the DPPH assays. Due to having different types of food acid, the acid regulator in the instant mango drink powder, it has got antioxidant

Table 4. Bioactive compounds of instant mango drink powder

\begin{tabular}{lcccc}
\hline \multirow{2}{*}{ Bioactive compounds } & \multicolumn{4}{c}{ Sample } \\
\cline { 2 - 5 } & A & B & C & D \\
\hline TAC (mg/100 g) & $0.9 \pm 0.00^{\mathrm{a}}$ & $0.5 \pm 0.00^{\mathrm{b}}$ & $0.9 \pm 0.00^{\mathrm{a}}$ & $0.2 \pm 0.00^{\mathrm{c}}$ \\
TFC (mg QE/100 g) & $29.3 \pm 0.01^{\mathrm{b}}$ & $19.0 \pm 0.01^{\mathrm{d}}$ & $25.7 \pm 0.01^{\mathrm{c}}$ & $32.2 \pm 0.02^{\mathrm{a}}$ \\
TPC (mg GAE/100 g) & $32.8 \pm 0.03^{\mathrm{a}}$ & $14.7 \pm 0.02^{\mathrm{c}}$ & $20.7 \pm 0.02^{\mathrm{b}}$ & $5.0 \pm 0.10^{\mathrm{d}}$ \\
Antioxidant Capacity (mg TE/100 g) & $22.1 \pm 0.03^{\mathrm{c}}$ & $28.0 \pm 0.02^{\mathrm{a}}$ & $22.6 \pm 0.02^{\mathrm{b}}$ & $19.7 \pm 0.02^{\mathrm{d}}$ \\
\hline
\end{tabular}

Significant at $\mathrm{P}<0.05$; Values followed by different superscript letters within the same row denote a significant difference. 
properties. Obilana et al. (2018) prepared instant beverage powder from extruded malted pearl millet (Babla) reported the antioxidant capacity as $1.78 \mu$ mole $\mathrm{TE} / \mathrm{g}$.

\subsection{Sensory evaluation of instant mango drink powder}

Table 5 shows the summary of sensory evaluation of the three formulated instant mango drink powder A, B, C, and commercial brand D. Sample D scored highest $(8.2 \pm 0.78)$ for color, while Sample B received highest scores for flavor $(8.3 \pm 0.67)$, taste $(8.3 \pm 0.67)$ and general acceptance (8.4 \pm 0.51$)$. Conversely, lowest score $(6.8 \pm 0.63)$ for color was recorded for sample B. Sample $D$ received lowest scores for flavor $(7.4 \pm 0.84)$ and taste (7.2 \pm 0.78$)$, and Sample $C$ was worst $(7.0 \pm 0.73)$ in terms of general acceptance. Instant mango drink powder, when added to water, is supposed to provide the real taste of fresh mango juice. The results of the sensory evaluation showed that the samples were significantly different $(p<0.05)$. This is why instant mango drinks, with its great taste and nutritional value, are highly preferred during the summer season. Comparative analysis of sensory attributes of our formulated mango drink powder and commercial brand powder revealed that Sample B scored high in the hedonic scale for most attributes, indicating its overall acceptability. Also, all three formulated instant mango drink powder appeared to be superior to the commercial brand powder in terms of all sensory attributes considered in this study except for color. Farzana et al. (2017) prepared instant soup powder from vegetable reported the Overall acceptability score as 8.5 .

\subsection{Microbiological quality of instant mango drink powder}

Safety, quality, and shelf life of a formulated instant mango drink powder are reflected by its microbiological characteristics. Total viable count, coliform, E. coli, yeast and mold count of all three formulated mango drink powder, and commercial brand mango drink powder were determined at 0,30 days, 60 days and 90 days of storage. The results obtained are shown in Table 6. In all samples total, the viable count was detected, but coliform, E. coli, and yeast and mold were not detected. During the time of the storage period, all the samples showed an increased total viable count. It may be due to improper handling of the samples during the processing of the products. The maximum moisture content of the samples was $4.6 \%$ after two months of storage, which was not favorable for microbial growth. Farzana et al. (2017) observed that TVC from vegetable-based instant soup powder was an initial $3.3 \times 10^{2} \mathrm{CFU} / \mathrm{g}$ to $2.7 \times 10^{4}$ $\mathrm{CFU} / \mathrm{g}$ at the end of shelf life of 180 days.

\section{Conclusion}

This study concludes that the development of instant mango drink powder has a huge potential as an exceptional value-added product as it would receive wide acceptance in terms of color, flavor, taste, and texture. The nutrient profile of the product was also fantastic from the health point of view as it contains less fat and more vitamins and minerals. The long-term storage capability of the product makes it commercially lucrative. Biochemical and sensory attributes of the formulated instant mango drink powder were either superior or comparable to existing mango drink powders. Microbiological analysis of our mango drink powder

Table 5. Sensory evaluation of instant mango drink powder

\begin{tabular}{lcccc}
\hline \multirow{2}{*}{ Parameter } & \multicolumn{4}{c}{ Sample } \\
\cline { 2 - 5 } & $\mathrm{A}$ & $\mathrm{B}$ & $\mathrm{C}$ & $\mathrm{D}$ \\
\hline Color & $7.4 \pm 0.96^{\mathrm{a}}$ & $6.8 \pm 0.63^{\mathrm{b}}$ & $7.3 \pm 0.15^{\mathrm{a}}$ & $8.2 \pm 0.78^{\mathrm{a}}$ \\
Flavor & $7.6 \pm 0.84^{\mathrm{a}}$ & $8.3 \pm 0.67^{\mathrm{a}}$ & $7.5 \pm 0.84^{\mathrm{a}}$ & $7.4 \pm 0.84^{\mathrm{a}}$ \\
Taste & $7.4 \pm 0.51^{\mathrm{a}}$ & $8.3 \pm 0.67^{\mathrm{ab}}$ & $7.5 \pm 0.17^{\mathrm{ab}}$ & $7.2 \pm 0.78^{\mathrm{c}}$ \\
Overall acceptability & $7.3 \pm 0.67^{\mathrm{a}}$ & $8.4 \pm 0.51^{\mathrm{ab}}$ & $7.0 \pm 0.73^{\mathrm{bc}}$ & $7.9 \pm 0.73^{\mathrm{c}}$ \\
\hline
\end{tabular}

Significant at $\mathrm{P}<0.05$; Values followed by different superscript letters within the same row denote a significant difference.

Table 6. Microbiological quality of the instant mango drink powder

\begin{tabular}{|c|c|c|c|c|c|c|c|}
\hline \multirow{2}{*}{ Sample } & \multicolumn{4}{|c|}{ TVC } & \multirow{2}{*}{$\mathrm{TCC}$} & \multirow{2}{*}{ E. coli } & \multirow{2}{*}{ Yeast and Mold } \\
\hline & 0 days & 30 days & 60 days & 90 days & & & \\
\hline A & $1.6 \times 10^{2}$ & $1.1 \times 10^{3}$ & $1.9 \times 10^{3}$ & $1.1 \times 10^{4}$ & \multirow{4}{*}{ ND } & \multirow{4}{*}{ ND } & \multirow{4}{*}{ ND } \\
\hline B & $1.4 \times 10^{2}$ & $1.2 \times 10^{3}$ & $2.0 \times 10^{3}$ & $1.3 \times 10^{4}$ & & & \\
\hline $\mathrm{C}$ & $1.8 \times 10^{2}$ & $1.3 \times 10^{3}$ & $1.8 \times 10^{3}$ & $1.2 \times 10^{4}$ & & & \\
\hline $\mathrm{D}$ & $1.1 \times 10^{2}$ & $1.0 \times 10^{3}$ & $1.7 \times 10^{3}$ & $1.0 \times 10^{4}$ & & & \\
\hline
\end{tabular}

$\mathrm{ND}=$ Not Detectable 
preparations indicates that these are safe to consume for at least three months after processing. As this powder contains significant amounts of protein, ash, vitamin $\mathrm{C}$, sodium, potassium, magnesium, calcium, iron, and energy, it can serve as a food supplement to improve the nutritional status of the country. Finally, with this formulation, people can have the taste of mango round the year, particularly when the season of fresh mango is over.

\section{Conflict of interest}

The authors declare no conflict of interest

\section{Acknowledgments}

The authors are highly thankful to Bangabandhu Science and Technology Fellowship for providing a fund to carry out this research. Authors would like to express gratefulness to the Department of Food Processing and Engineering, Department of Physiology, Biochemistry and Pharmacology and Poultry Research and Training Center (PRTC) of Chattogram Veterinary and Animal Sciences University (CVASU) for institutional support and assistance.

\section{References}

Akhter, S., Abid, H., Yasmin, A. and Masood, S. (2010). Preparation and evaluation of physical and chemical characteristics of instant mango juice powder. Pakistan Journal of Biochemistry and Molecular Biology, 43(2), 58-60.

Alam, M., Islam, M., Uddin, M., Barman, J. and Quamruzzaman, A. (2006). Effect of age of seedling and variety of scion in stone grafting of mango. International Journal of Sustainable Crop Production, 1(2), 27-32.

AOAC. (2000). Official methods of analysis. 17th ed. Maryland, USA: Association of Official Analytical Chemists.

Atallah, A. (2015). Development of new functional beverages from milk permeate using some probiotic bacteria and fruits pulp. Egyptian Journal of Dairy Science, 43(1), 25-39.

Azlim Almey, A., Ahmed Jalal Khan, C., Syed Zahir, I., Mustapha Suleiman, K., Aisyah, M. and Kamarul Rahim, K. (2010). Total phenolic content and primary antioxidant activity of methanolic and ethanolic extracts of aromatic plants' leaves. International Food Research Journal, 17(4), 10771084.

Chang, C.C., Yang, M.H., Wen, H.M. and Chern, J.C. (2002). Estimation of total flavonoid content in propolis by two complementary colorimetric methods. Journal of Food and Drug Analysis, 10(3), 178-182.

Chen, C.C., Mergens, W.J. and Milbank, M.C. (2000). Vitamin powders for beverage applications and method of making. US Patent No. 6162474A, DSM Nutritional Products LLC.

El Wakeel, M. (2007). Ultra structure and functional properties of some dry mixes of food. Faculty of Agriculture, Ain Shams University, Cairo, MSc. Thesis.

Farzana, T., Mohajan, S., Saha, T., Hossain, M.N. and Haque, M.Z. (2017). Formulation and nutritional evaluation of a healthy vegetable soup powder supplemented with soy flour, mushroom, and moringa leaf. Food Science and Nutrition, 5(4), 911920. https://doi.org/10.1002/fsn3.476

Fitzpatrick, J.J. (2005). Food powder flowability. Encapsulated and powdered foods. $2^{\text {nd }}$ ed. USA: CRC Press. https:// doi.org/10.1201/9781420028300.ch10

James, C.S. (1995). Analytical Chemistry of Foods. 1st ed. New York: Blackie Academic and Professional. https://doi.org/10.1007/978-1-4615-2165-5

Johnson, R. and Raymond, W. (1965). The chemical composition of some tropical food plants. 5. Mango. Tropical Science, 7, 109-164.

Kabir, Y., Shekhar, H.U. and Sidhu, J.S. (2017). Phytochemical compounds in functional properties of mangoes. In Siddiq, M., Brecht, J.K. and Sidhu, J.S. (Eds). Handbook of Mango Fruit: Production, Postharvest Science, Processing Technology and Nutrition, p. 237-254. United Kingdom: Wiley. https://doi.org/10.1002/9781119014362.ch12

Kermode, G. (1972). Food additives. Scientific American, 226(3), 15-21. https://doi.org/10.1038/ scientificamerican0372-15

Khodjaeva, U., Bojnanska, T., Vietoris, V., Sytar, O. and Singh, R. (2013). Food additives as important part of functional food. International Research Journal of Biological Sciences, 2(4), 1-6.

Kroger, M., Meister, K. and Kava, R. (2006). Lowcalorie sweeteners and other sugar substitutes: a review of the safety issues. Comprehensive Reviews in Food Science and Food Safety, 5(2), 35-47. https://doi.org/10.1111/j.1541-4337.2006.tb00081.x

Ma, X., Wu, H., Liu, L., Yao, Q., Wang, S., Zhan, R., Xing, S. and Zhou, Y. (2011). Polyphenolic compounds and antioxidant properties in mango fruits. Scientia Horticulturae, 129(1), 102-107.

Mahendran, T. (2011). Physico-chemical properties and sensory characteristics of dehydrated guava 
concentrate: effect of drying method and maltodextrin concentration. Tropical Agricultural Research and Extension, 13(2), 48-54. https:// doi.org/10.4038/tare.v13i2.3138

McClements, D.J. (2015). Food emulsions: principles, practices, and techniques. $3^{\text {rd }}$ ed. Boca Raton London: CRC Press. https://doi.org/10.1201/b18868

Mirza, S.K., Asema, U. and Kasim, S.S. (2017). To study the harmful effects of food preservatives on human health. Journal of Medicinal Chemistry and Drug Discovery, 2(2), 610-616.

Mohammed, S., Gimba, I. and Bahago, E. (2017). Production and Quality Evaluation of Instant Sorrel (Zobo) Drink Produced by Infusion, Dehydration and Size Reduction Methods. Journal of Nutrition and Health Sciences, 4(2), 1-10. https:// doi.org/10.15744/2393-9060.4.205

Mustafa, F. and Medeiros, D. (1985). Proximate composition, mineral content, and fatty acids of catfish (Ictalurus punctatus, Rafinesque) for different seasons and cooking methods. Journal of Food Science, 50(3), 585-588. https:// doi.org/10.1111/j.1365-2621.1985.tb13749.x

Najwa, F.R. and Azrina, A. (2017). Comparison of vitamin $\mathrm{C}$ content in citrus fruits by titration and high performance liquid chromatography (HPLC) methods. International Food Research Journal, 24 (2), 726-733.

Obilana, A.O., Odhav, B. and Jideani, V.A. (2018). Nutritional, biochemical and sensory properties of instant beverage powder made from two different varieties of pearl millet. Food and Nutrition Research, 62, 1524. https://doi.org/10.29219/ fnr.v62.1524

Pap, L. (1995). Production of pure vegetable juice powders of full biological value. Fruit Process, 3, 55 -60 .

Pitkanen, T., Paakkari, P., Miettinen, I.T., HeinonenTanski, H., Paulin, L. and Hanninen, M.L. (2007). Comparison of media for enumeration of coliform bacteria and Escherichia coli in non-disinfected water. Journal of Microbiological Methods, 68(3), 522-529.

https://doi.org/10.1016/ j.mimet.2006.10.007

Saxena, R. and Arora, V. (1997). Consumers of processed fruit and vegetable products: an analysis of buying behaviour. Indian Food Industry, 16, 2536.

Seiler, D. (1985). Monitoring mycological media. International Journal of Food Microbiology, 2(1-2), 123-131. https://doi.org/10.1016/0168-1605(85) 90066-2
Swartzberg, J. and Margen, S. (2001). Eat, Drink, and Be Healthy: The Harvard Medical School Guide to Healthy Eating. American Journal of Epidemiology, 154(12), 1160-1160. https://doi.org/10.1093/ aje/154.12.1160-a

Thind, K., Grewal, K. and Bakshi, A. (2002). Method of preparation and keeping quality of reconstituted skim milk based mango beverage. Beverage and Food World, 29(8), 60-62.

Unal, K., Susanti, D. and Taher, M. (2014). Polyphenol content and antioxidant capacity in organically and conventionally grown vegetables. Journal of Coastal Life Medicine, 2(11), 864-871. 